\title{
ANALISIS KEBUTUHAN AIR IRIGASI DI DAERAH IRIGASI SERAYU KECAMATAN SUMPIUH KABUPATEN BANYUMAS
}

\section{ANALYSIS OF IRRIGATION WATER SUPPLY IN THE SERAYU IRRIGATION AREA SUMPIUH DISTRICT, BANYUMAS REGENCY}

\author{
Teguh Marhendi ${ }^{1}$, Imtinan Khoirunissa ${ }^{2}$ \\ ${ }^{1,2}$ Program Studi S1 Teknik Sipil, Fakultas Teknik dan Sains \\ Universitas Muhammadiyah Purwokerto
}

Informasi Artikel

Dikirim,

Direvisi,

Diterima,

\section{Korespondensi Penulis:}

Teguh Marhendi Program Studi Teknik Sipil Universitas Muhammadiyah Purwokerto

JL. K.H. Ahmad Dahlan Purwokerto, 53182

Email:

tmarhendi@gmail.com, teguhmarhendi@ump.ac.id

\section{ABSTRAK}

Daerah Irigasi Serayu berada di bawah pengelolaan Perwakilan Balai Wilayah Tajum, Balai PSDA Serayu Citanduy Dinas PSDA Propinsi Jawa Tengah. Daerah Irigasi Serayu terletak di Kecamatan Sumpiuh, Kabupaten Banyumas, Jawa Tengah. Daerah irigasi ini memiliki total daerah cakupan pengairan lebih kurang $210 \mathrm{~km}^{2}$ yang terbentang di 3 Kabupaten, yaitu Kabupaten Banyumas, Kabupaten Cilacap dan sebagian wilayah Kabupaten Kebumen. Pada tahun 2019 lalu, kebutuhan air irigasi serayu direncanakan sudah cukup memenuhi kebutuhan. Namun pada hasilnya masih terdapat kekurangan yang disebabkan karena adanya perbaikan-perbaikan saluran yang membuat faktor kehilangan air menjadi tinggi. Penelitian ini dimaksudkan untuk mengetahui kebutuhan air irigasi di daerah irigasi Serayu di Kecamatan Sumpiuh dengan acuan Pola Tanam tahun 2020. Hasil penelitian ini menunjukkan bahwa pada kebutuhan air irigasi saluran sekunder sumpiuh hasil perhitungan, angka terbesarnya ada pada MT I bulan November periode II yaitu 423,14 lt/dt sedangkan angka terkecilnya di MT III bulan Juni periode 1 yaitu 146,82 lt/dt. Lalu kebutuhan air irigasi saluran sekunder sumpiuh di lapangan, angka terbesarnya ada pada MT I bulan Oktober periode II dan MT III bulan September periode II yaitu 267,00 lt/dt sedangkan angka terkecilnya di MT II bulan April periode 1 yaitu 136,00 lt/dt. Pada kebutuhan air irigasi saluran sekunder selandaka hasil perhitungan, angka terbesarnya ada pada MT I bulan November periode II yaitu 13,66 lt/dt sedangkan angka terkecilnya di MT III bulan Juni periode 1 yaitu 39,36 lt/dt. Lalu kebutuhan air irigasi saluran sekunder sumpiuh di lapangan, angka terbesarnya ada pada MT I bulan Oktober periode II dan MT III bulan September periode II yaitu 25,00 lt/dt sedangkan angka terkecilnya di MT II bulan Maret periode 1 yaitu 8,00 lt/dt.

Kata Kunci : Kebutuhan Air Irigasi, Pola Tanam 2020, Daerah irigasi Serayu

\begin{tabular}{|c|}
\hline 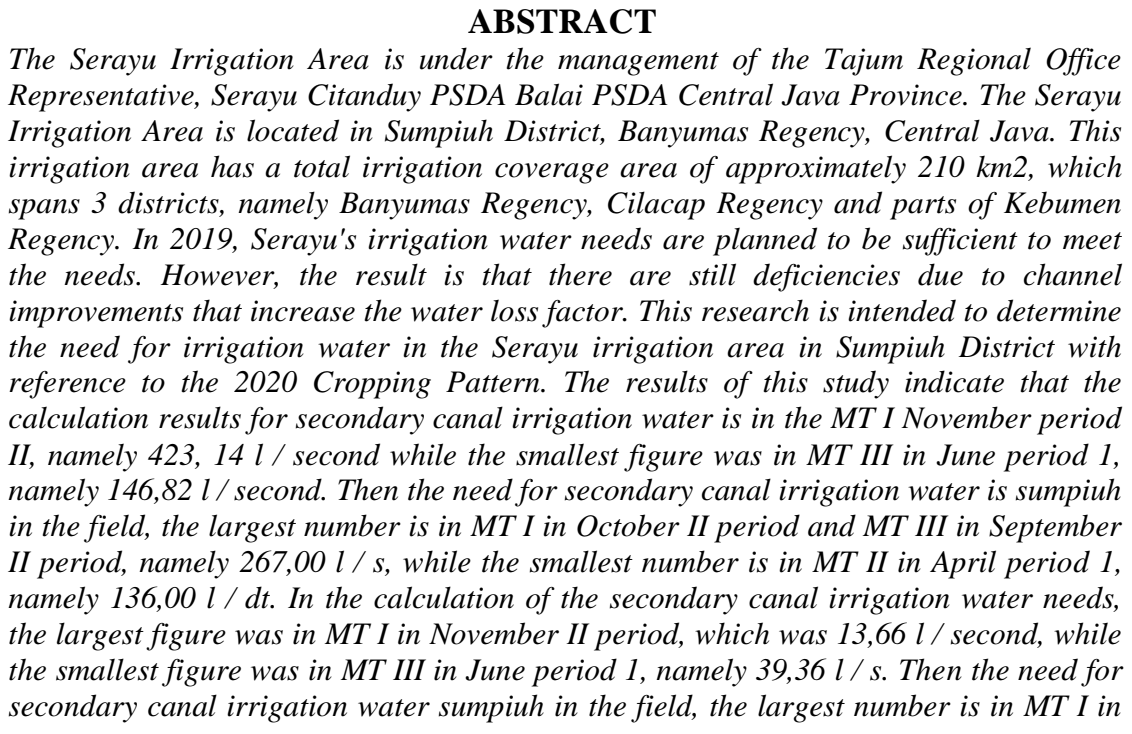 \\
\hline
\end{tabular}


October II period and MT III in September II period, which is 25,00 l / s, while the smallest number is in MT II in March period 1, namely 8,00 l/ sec. dt.

Keyword : Irrigation Water Supply, 2020 's Planting Patterns, Serayu Irrigation Area

\section{PENDAHULUAN}

Kabupaten Banyumas merupakan salah satu kabupaten di Provinsi Jawa Tengah yang memiliki luas wilayah sebesar 1.329,02 km² dengan total populasi penduduk 1.578.129 jiwa terdaftar pada tahun 2013. Secara administratif, Kabupaten Banyumas memiliki 27 kecamatan dan 331 kelurahan. Dari total luas wilayah tersebut, sekitar 24,19\% atau 32.155 Ha merupakan lahan sawah dimana 25.766 Ha adalah sawah irigasi dan 6.389 Ha adalah sawah tadah [1] [2].

Daerah Irigasi Serayu berada di bawah pengelolaan Perwakilan Balai Wilayah Tajum, Balai PSDA Serayu Citanduy Dinas PSDA Propinsi Jawa Tengah. Daerah Irigasi Serayu terletak di Kecamatan Kebasen, Kabupaten Banyumas, Jawa Tengah. Daerah irigasi ini memiliki total daerah cakupan pengairan lebih kurang $210 \mathrm{~km}^{2}$ yang terbentang di 3 Kabupaten, yaitu Kabupaten Banyumas, Kabupaten Cilacap dan sebagian wilayah Kabupaten Kebumen [1] [2].
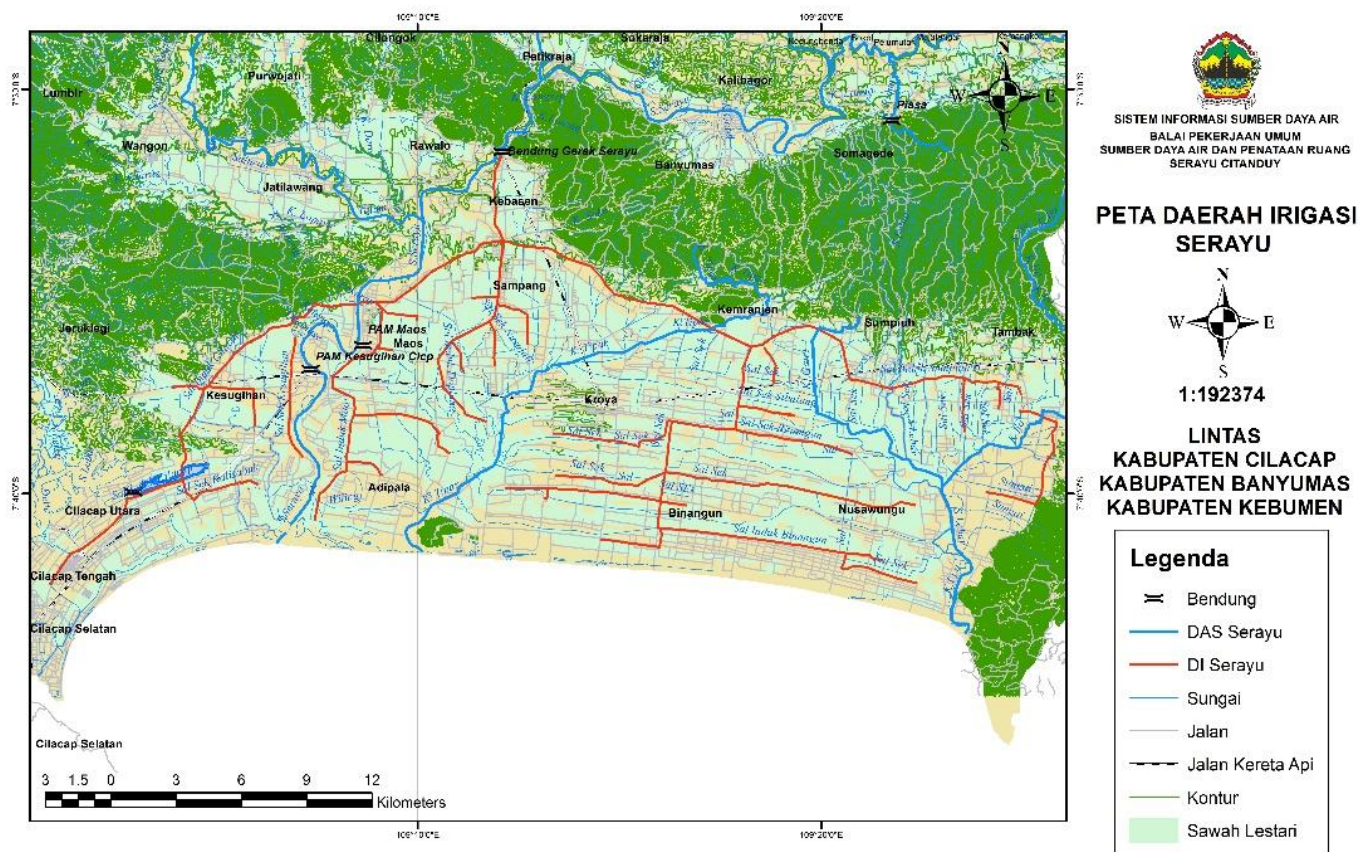

PETA DAERAH IRIGASI SERAYU

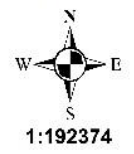

LINTAS

KABUPATEN CILACAP

KABUPATEN BANYUMAS

KABUPATEN KEBUMEN

Legenda

$=$ Bendung

- DAS Serayu

- DI Serayu

- Sungai

Jalan

-.- Jalan Kereta Api

- Kontur

Sawah Lestari

Gambar 1. Peta Daerah Irigasi Serayu [2]

Dalam merencanakan besarnya debit kebutuhan air yang diperlukan pada areal persawahan secara keseluruhan perlu dilakukan suatu analisa kebutuhan air mulai dari saluran pembawa yaitu saluran primer, saluran sekunder dan saluran tersier hingga besarnya kebutuhan di petak-petak sawah, dalam hal ini perlu didukung dengan kelengkapan data-data yang terkait dalam analisa ini untuk mendapatkan hasil yang optimal [2] [3] [4] [5] [6].

Bendung Gerak Serayu memiliki 3 saluran induk yang paling utama, yaitu Saluran Induk Sumpiuh, Cilacap dan Doplang. Pada Saluran Induk Sumpiuh terdapat 28 saluran sekunder. Lalu pada Saluran Induk Cilacap terdapat 12 saluran sekunder, sedangkan pada Saluran Induk Doplang sebanyak 4 saluran sekunder [2] [3] [4] [5] [6]. 


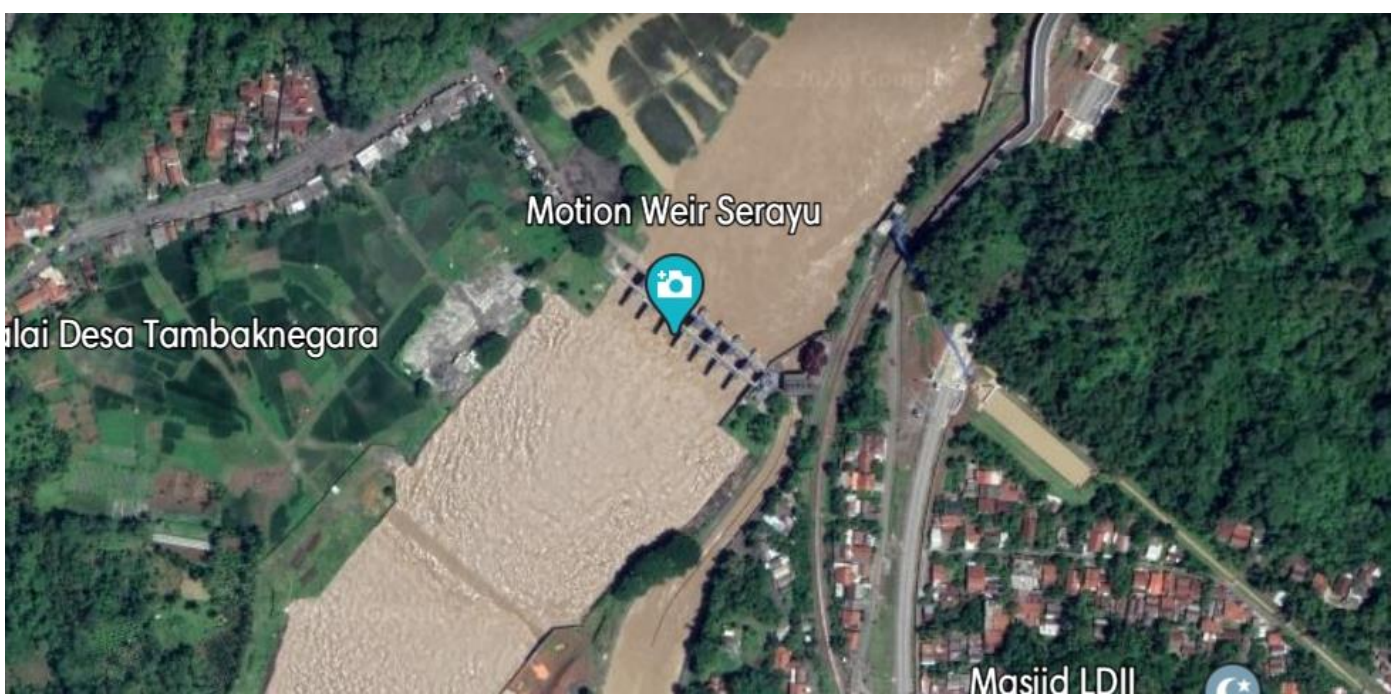

Gambar 2. Peta Lokasi Bendung Gerak Serayu [7]

Kebutuhan air bagi tanaman didefinisikan sebagai tebal air yang dibutuhkan untuk memenui jumlah air yang hilang melalui evapotranspirasi suatu tanaman sehat, tumbuh pada areal yang luas, pada tanah yang menjamin cukup lengas tanah, kesuburan tanah, dan lingkungan hidup tanaman cukup baik sehingga secara potensial tanaman akan berproduksi secara baik [8][12][14][15]. Kebutuhan air tanaman dipengaruhi oleh beberapa faktor evaporasi, transpirasi yang kemudian dihitung sebagai evapotranspirasi [9]. Pemberian air secara golongan adalah untuk efisiensi, memperkecil kapasitas saluran pembawa, dan seringkali untuk menyesuaikan pelayanan irigasi menurut variasi debit yang tersedia pada tempat penangkap air, misalnya bendung pada sungai [8][9][10][11][16].

Kecamatan Sumpiuh terletak di Kabupaten Banyumas dengan luas wilayah $60,01 \mathrm{~km}^{2}$ yang terbagi menjadi 14 Kelurahan. Kecamatan Sumpiuh memiliki potensi pertanian lahan yang cukup luas yaitu 1.604 Ha, dari luas tersebut sawah yang mempunyai irigasi teknis yaitu seluas 1.409 Ha. Suplai air untuk irigasi di Kecamatan Sumpiuh berasal dari Sungai Serayu melalui Bendungan Gerak Serayu Gambarsari. Daerah Irigasi Serayu dengan Saluran Induk Sumpiuh memiliki luas areal sebesar 1.192,45 Ha dengan debit aliran $8.020 \mathrm{~m}^{3} / \mathrm{dt}^{\mathrm{d}}$ per periode 16-31 Maret 2020 [1].

\section{METODE PENELITIAN}

\subsection{Lokasi Penelitian}

Lokasi pada penelitian ini yaitu Daerah Irigasi Serayu yang terletak di Kecamatan Sumpiuh, Kabupaten Banyumas, Jawa Tengah.

\subsection{Data penelitian}

Data yang diperlukan dalam penelitian ini yaitu data sekunder yang diperoleh melalui kajian pustaka dari pihak Dinas terkait seperti Dinas Balai PSDA Serayu Citanduy Dinas PSDA Jawa Tengah dan Dinas Pertanian dan Ketahanan Pangan Kabupaten Banyumas. Data-data yang diperlukan dalam penelitian ini adalah:

a. Peta yang terdiri dari peta topografi dan peta daerah irigasi,

b. Skema jaringan irigasi sekunder serta skema bangunan irigasi,

c. Data curah hujan Tahun 2010-2019,

d. Data klimatologi Tahun 2010-2019,

e. Data rencana pola tanam 2019-2020 dan jenis tanaman, 


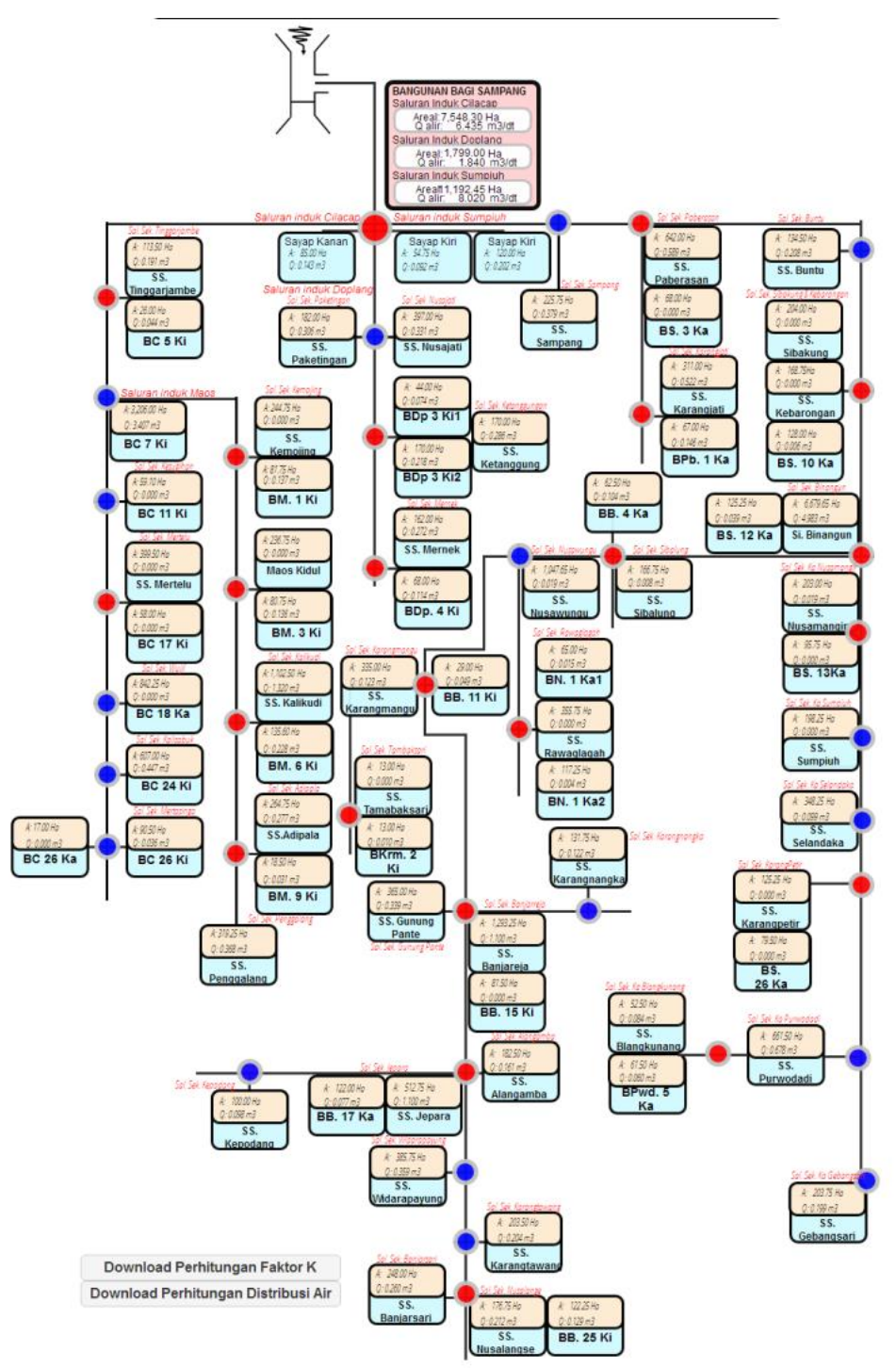

Gambar 3. Skema Jaringan Irigasi Serayu [17]

\subsection{Prosedur Penelitian dan Analisis Data Penelitian}

Tahap Pelaksanaan Penelitian ini yaitu tahap dimulainya mengambilan data-data yang diperlukan dan pengolahan data tersebut sehingga diperolah hasil analisis yang sesuai.

\section{Persiapan Penelitian}

Tahap Persiapan Penelitian merupakan rangkaian kegiatan sebelum penelitian dilaksanakan. Dalam tahap awal ini disusun hal-hal penting yang harus dilakukan dengan tujuan supaya kegiatan terstruktur, terkoordinasi dan mendapatkan hasil seperti yang direncanakan meliputi penggambilan data-data yang diperlukan dari pihak terkait yaitu Kantor Balai PSDA Serayu Citanduy dan Kantor Dinas Pertanian dan Ketahanan Pangan. Tahapannya antara lain:

a. Menentukan lokasi penelitian.

b. Mencari rumusan masalah yang akan dianalisis.

c. Mencari tinjauan pustaka yang berkaitan.

d. Menentukan data-data apa saja yang dibutuhkan.

\section{Pelaksanaan Penelitian}

Tahap Pelaksanaan Penelitian ini yaitu tahap dimulainya mengambilan data-data yang diperlukan dan pengolahan data tersebut sehingga diperolah hasil analisis yang sesuai. 


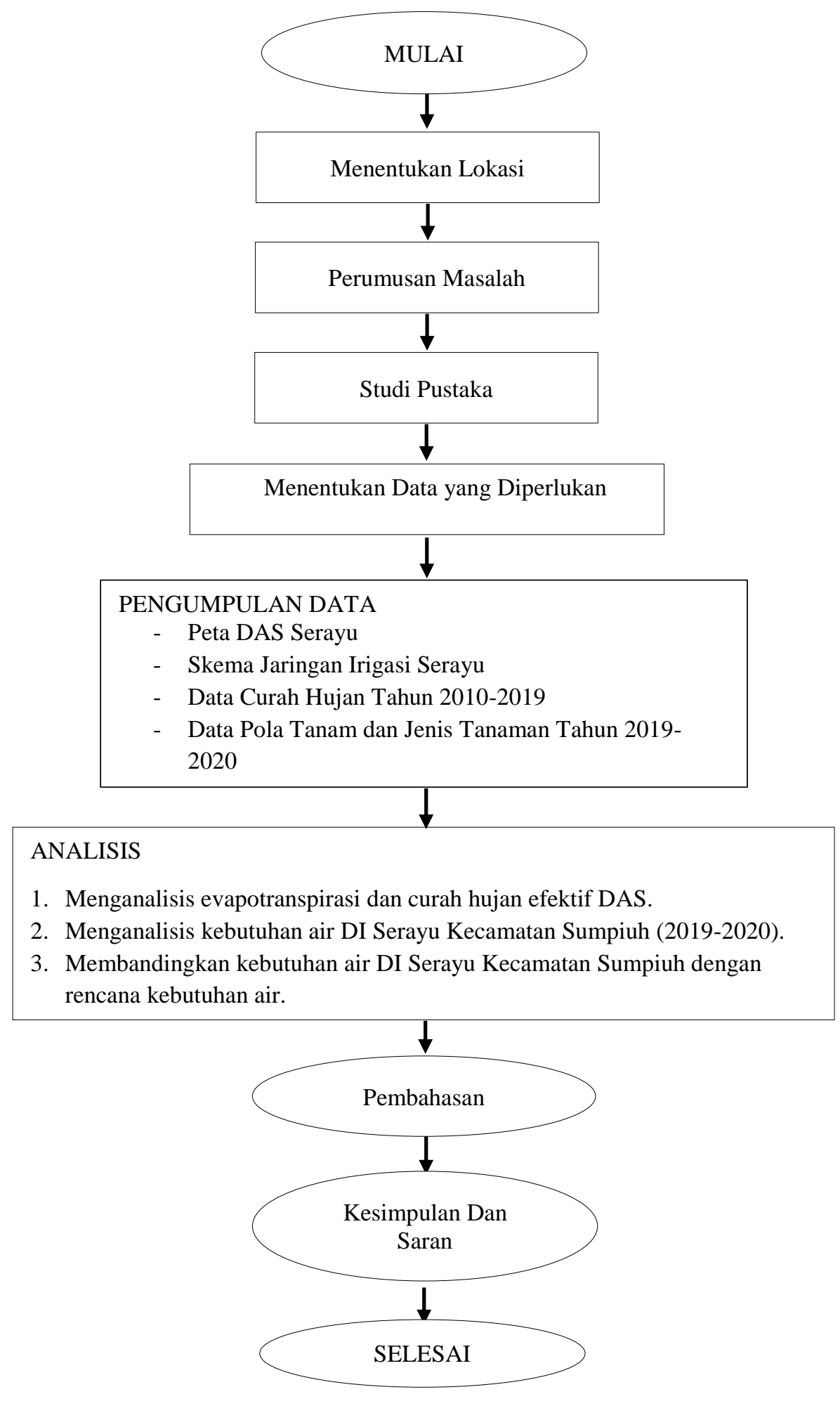

Gambar 4. Bagan Alir Metode Penelitian 


\section{Analisis Data}

Dalam penelitian ini ada beberapa tahapan analisis yang dilakukan antara lain:

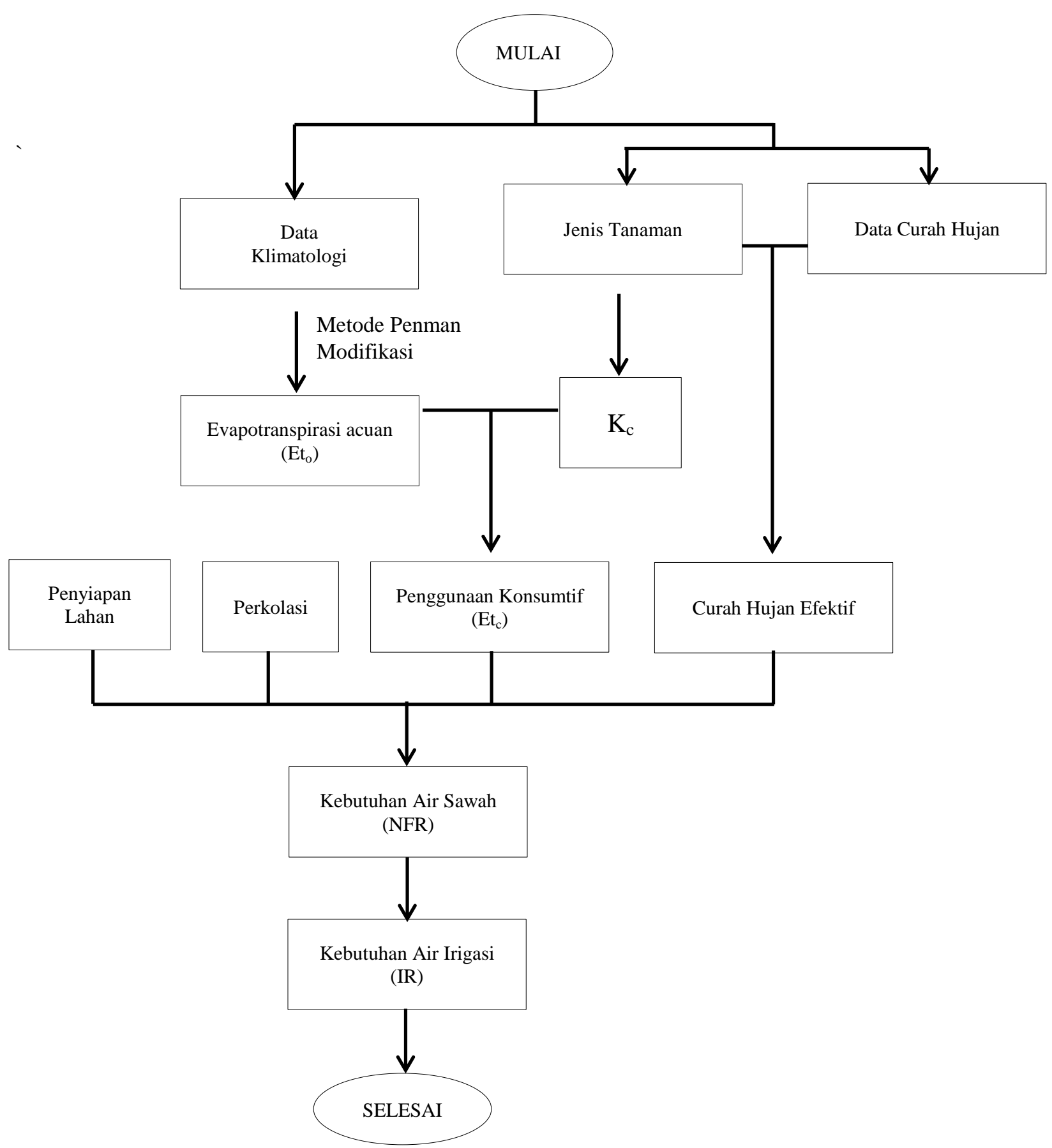

Gambar 5. Skema Analisis Kebutuhan Air Irigasi

\section{Pola Tanam dan Jenis Tanaman}

Pola tanam yang digunakan pada penelitian ini adalah rencana pola tanam Kabupaten Banyumas Tahun 2019-2020 yang dibagi menjadi 3 masa tanam dengan jenis tanaman padi dan palawija. Tanaman palawija di Daerah Irigasi Serayu Kecamatan Sumpiuh diasumsikan tanaman kacang tanah karena sebagian besar petani menanam kacang tanah [13][14]. 
Dari jenis tanaman yang diketahui maka didapatkan nilai koefisien tanaman $(\mathrm{Kc})$. Nilai tersebut ada pada Tabel 2.3 untuk padi dan Table 2.4 untuk palawija. Koefisien tanaman digunakan untuk menghitung Penggunaan konsumtif (Etc) dengan cara dikalikan dengan Evapotransitasi acuan (Eto) [11][13][15].

\section{Analisis Kebutuhan Air Irigasi}

Untuk menganalisa kebutuhan air irigasi maka harus diketahui terlebih dulu besaran kebutuhan air untuk pengolahan tanah (S), evapotranspirasi (Eto), perkolasi (P) dan curah hujan efektif yang terjadi pada 2010 hingga 2019 [4][8][16].

$$
I R=S+E_{t o}+P-R e
$$

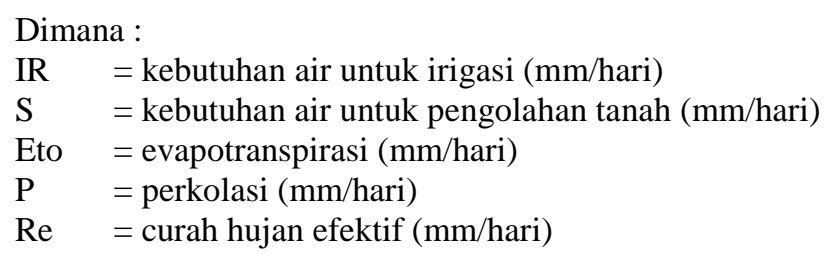

\section{HASIL DAN PEMBAHASAN}

\subsection{Curah Hujan Rata - Rata}

Cara Perhitungan curah hujan rata - rata 30 hari di DAS Sungai Serayu dengan menggunakan Metode Poligon Thiessen. Adapun jumlah stasiun yang masuk di lokasi DAS Sungai Serayu berjumlah tiga buah stasiun yaitu Sta. Sokaraja, Sta. Gambarsari dan Sta. Kranji. Penentuan luas pengaruh stasiun hujan dengan Metode Thiessen, dari dua stasiun tersebut masing-masing dihubungkan untuk memperoleh luas daerah pengaruh dari tiap stasiun. Di mana masing - masing stasiun mempunyai daerah pengaruh yang dibentuk dengan garis - garis sumbu tegak lurus terhadap garis penghubung antara stasiun, dapat dilihat pada gambar 6.

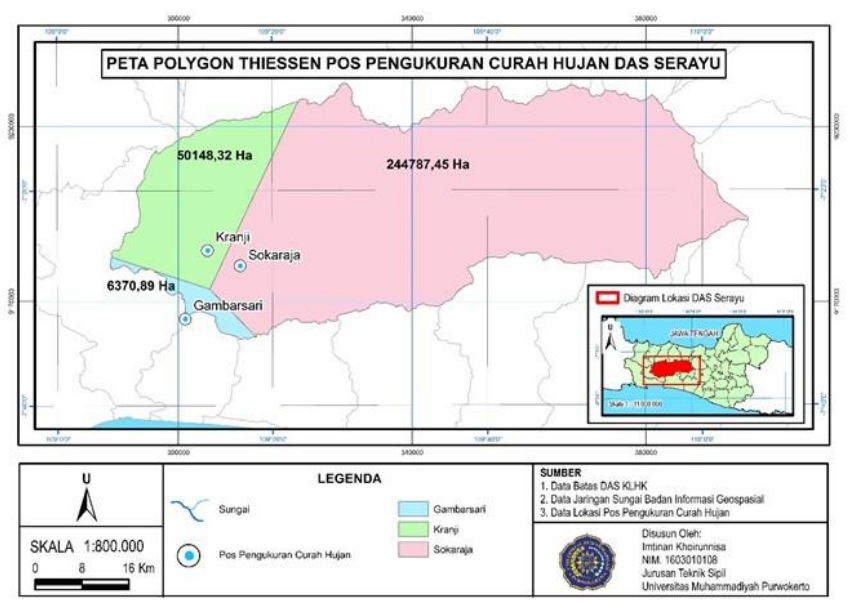

Gambar 6. Metode Poligon Thiessen untuk analisis hujan

Didapat data curah hujan selama 10 tahun pada Stasiun Sokaraja, Stasiun Gambarsari dan Stasiun Kranji yang terdapat pada lampiran. Data curah hujan dan luasan DAS Sungai Serayu berdasarkan Metode Poligon Thiessen dihitung untuk mencari Rerata Curah Hujan per tahun dapat dilihat perhitugan pada tabel 1. sampai tabel 4. berikut :

Tabel 1. Perhitungan Curah Hujan Rata Rata (Sta. Sokaraja)

\begin{tabular}{ccccc}
\hline Tahun & $\begin{array}{c}\text { Jumlah } \\
\text { Curah } \\
\text { Hujan } \\
(\mathrm{mm})\end{array}$ & $\begin{array}{c}\text { Jumlah } \\
\text { Hari Hujan } \\
\text { Pertahun }\end{array}$ & $\begin{array}{c}\text { Rerata } \\
\text { Curah } \\
\text { Hujan } \\
\text { Perhari } \\
(\mathrm{mm})\end{array}$ & $\begin{array}{c}\text { Luas Daerah } \\
\text { Stasiun }\end{array}$ \\
\hline 2010 & 5006 & 199 & 25,156 & 244787,45 \\
2011 & 3483 & 151 & 23,066 & 244787,45 \\
2012 & 3012 & 110 & 27,382 & 244787,45
\end{tabular}




\begin{tabular}{lllll}
2013 & 3488 & 140 & 24,914 & 244787,45 \\
2014 & 3197 & 129 & 24,783 & 244787,45 \\
2015 & 2977 & 105 & 28,352 & 244787,45 \\
2016 & 4270 & 179 & 23,855 & 244787,45 \\
2017 & 4672 & 165 & 28,315 & 244787,45 \\
2018 & 2625 & 105 & 25,000 & 244787,45 \\
2019 & 2016 & 95 & 21,221 & 244787,45 \\
\hline
\end{tabular}

Tabel 2. Perhitungan Curah Hujan Rata Rata (Sta. Gambarsari)

\begin{tabular}{ccccc}
\hline Tahun & $\begin{array}{c}\text { Jumlah } \\
\text { Curah } \\
\text { Hujan } \\
(\mathrm{mm})\end{array}$ & $\begin{array}{c}\text { Jumlah } \\
\text { Hari Hujan } \\
\text { Pertahun }\end{array}$ & $\begin{array}{c}\text { Rerata } \\
\text { Curah } \\
\text { Hujan } \\
\text { Perhari } \\
(\mathrm{mm})\end{array}$ & $\begin{array}{c}\text { Luas } \\
\text { Daerah } \\
\text { Stasiun }\end{array}$ \\
\hline 2010 & 4381 & 202 & 21,688 & 50148,32 \\
2011 & 2516 & 133 & 18,917 & 50148,32 \\
2012 & 1805 & 106 & 17,028 & 50148,32 \\
2013 & 2873 & 173 & 16,607 & 50148,32 \\
2014 & 2151 & 134 & 16,052 & 50148,32 \\
2015 & 2231 & 113 & 19,743 & 50148,32 \\
2016 & 3545 & 191 & 18,560 & 50148,32 \\
2017 & 2233 & 175 & 12,760 & 50148,32 \\
2018 & 1651 & 131 & 12,603 & 50148,32 \\
2019 & 1189 & 112 & 10,616 & 50148,32 \\
\hline
\end{tabular}

Tabel 3. Perhitungan Curah Hujan Rata Rata (Sta. Kranji)

\begin{tabular}{ccccc}
\hline Tahun & $\begin{array}{c}\text { Jumlah } \\
\text { Curah } \\
\text { Hujan } \\
(\mathrm{mm})\end{array}$ & $\begin{array}{c}\text { Jumlah } \\
\text { Hari Hujan } \\
\text { Pertahun }\end{array}$ & $\begin{array}{c}\text { Rerata } \\
\text { Curah } \\
\text { Hujan } \\
\text { Perhari } \\
(\mathrm{mm})\end{array}$ & $\begin{array}{c}\text { Luas } \\
\text { Daerah } \\
\text { Stasiun }\end{array}$ \\
\hline 2010 & 3369 & 201 & 16,761 & 6370,89 \\
2011 & 1901 & 92 & 20,663 & 6370,89 \\
2012 & 2131 & 90 & 23,678 & 6370,89 \\
2013 & 2479 & 111 & 22,333 & 6370,89 \\
2014 & 1654 & 65 & 25,446 & 6370,89 \\
2015 & 1009 & 49 & 20,592 & 6370,89 \\
2016 & 660 & 38 & 17,368 & 6370,89 \\
2017 & 999 & 49 & 20,388 & 6370,89 \\
2018 & 1414 & 73 & 19,370 & 6370,89 \\
2019 & 1002 & 86 & 11,651 & 6370,89 \\
\hline
\end{tabular}

Tabel 4. Perhitungan Curah Hujan dengan Metode Poligon Thiessen

\begin{tabular}{ccc}
\hline No & Rerata Curah Hujan $(\mathrm{mm}) /$ PerTahun \\
\hline 1 & 2010 & 200,55 \\
2 & 2011 & 126,10 \\
3 & 2012 & 102,04 \\
4 & 2013 & 138,44 \\
5 & 2014 & 105,64 \\
6 & 2015 & 90,51 \\
7 & 2016 & 141,76 \\
8 & 2017 & 128,60 \\
9 & 2018 & 99,87 \\
10 & 2019 & 96,74 \\
\hline
\end{tabular}

Perhitungan curah hujan rerata tiap Stasiun Curah hujan didapat dari jumlah curah hujan dan jumlah hari hujan pertahun (PSDA Citanduy) dengan perhitungan sebagai berikut:

Curah Hujan Rerata Perhari $(\mathrm{mm})=\frac{\text { Jumlah Curah Hujan }(\mathrm{mm})}{\text { Jumlah Hari Hujan Pertahun }}$ 
Setelah dihitung curah hujan rerata perhari ( $\mathrm{mm})$ setiap stasiun curah hujan Sokaraja, Gambarsari, dan Kranji selama 10 tahun terakhir. Selanjutnya menghitung rerata curah hujan (mm)/ pertahun selama 10 tahun terakhir dengan perhitung sebagai berikut :

$$
\bar{R}=\frac{A_{1} R_{1}+A_{2} R_{2}+A_{3} R_{3}}{A_{1}+A_{2}+A_{3}}
$$

dimana :

$\overline{\mathrm{R}} \quad=$ Curah hujan rata-rata Pertahun ( $\mathrm{mm} /$ Pertahun)

A1 = Luas pengaruh dari stasiun pengamatan St. Sokaraja (ha)

A2 $=$ Luas pengaruh dari stasiun pengamatan St. Gambarsari (ha)

A3 = Luas pengaruh dari stasiun pengamatan St. Kranji (ha)

$\overline{\mathrm{R}} 1 \quad=$ Curah hujan rata-rata Pertahun St. Sokaraja $(\mathrm{mm})$

$\overline{\mathrm{R}} 2=$ Curah hujan rata-rata Pertahun St. Gambarsari (mm)

$\overline{\mathrm{R}} 3 \quad$ = Curah hujan rata-rata Pertahun St. Kranji (mm)

\subsection{Curah Hujan Efektif ( Re )}

Curah hujan efektif adalah curah hujan yang secara efektif dan secara langsung dipergunakan memenuhi kebutuhan air tanaman untuk pertumbuhan. Besarnya curah hujan efektif untuk tanaman ditentukan sebesar $80 \%$ dari curah hujan rerata per 15 harian bulanan dengan kemungkinan kegagalan $20 \%$ atau dapat juga disebut dengan curah hujan $R_{80}$ untuk perhitungan curah hujan efektif ini menggunakan Metode Basic Year dengan rumus: $R_{80}=\frac{n}{5}+1$ dengan $\mathrm{n}$ adalah periode lama pengamatan [3].

Tabel 5. Curah Hujan Efektif (Re)

\begin{tabular}{|c|c|c|c|c|}
\hline \multirow{2}{*}{$\begin{array}{c}\text { Jenis } \\
\text { Tanaman }\end{array}$} & \multirow{2}{*}{ Bulan } & \multirow{2}{*}{ Periode } & \multicolumn{2}{|c|}{ Curah Hujan Efektif } \\
\hline & & & Re Padi & Re Palawija \\
\hline \multirow{8}{*}{ Padi } & \multirow{2}{*}{ Okt } & I & 0,01 & 0,01 \\
\hline & & II & 0,21 & 0,15 \\
\hline & \multirow{2}{*}{ Nov } & I & 0,66 & 0,47 \\
\hline & & II & 0,53 & 0,38 \\
\hline & \multirow{2}{*}{ Des } & I & 0,54 & 0,39 \\
\hline & & II & 0,84 & 0,60 \\
\hline & \multirow{2}{*}{ Jan } & I & 0,95 & 0,68 \\
\hline & & II & 0,89 & 0,63 \\
\hline \multirow{8}{*}{ Padi } & \multirow{2}{*}{ Feb } & I & 0,79 & 0,57 \\
\hline & & II & 0,78 & 0,56 \\
\hline & \multirow{2}{*}{ Mar } & I & 0,52 & 0,37 \\
\hline & & II & 0,70 & 0,50 \\
\hline & \multirow{2}{*}{ Apr } & I & 0,68 & 0,48 \\
\hline & & II & 0,52 & 0,37 \\
\hline & \multirow{2}{*}{ Mei } & I & 0,14 & 0,10 \\
\hline & & II & 0,23 & 0,16 \\
\hline \multirow{8}{*}{ Palawija } & \multirow{2}{*}{ Jun } & I & 0,16 & 0,11 \\
\hline & & II & 0,08 & 0,06 \\
\hline & \multirow{2}{*}{ Jul } & I & 0,00 & 0,00 \\
\hline & & II & 0,00 & 0,00 \\
\hline & \multirow{2}{*}{ Agst } & I & 0,00 & 0,00 \\
\hline & & II & 0,00 & 0,00 \\
\hline & \multirow{2}{*}{ Sep } & I & 0,00 & 0,00 \\
\hline & & II & 0,00 & 0,00 \\
\hline
\end{tabular}

Sumber : Hasil Perhitungan, 2020 


\subsection{Analisis Kebutuhan Air Irigasi \\ Evapotranspirasi (Eto)}

Perhitungan Evaportanspirasi dapat dihitung dengan menggunakan Metode Branley Criddle. Hasil perhitungan evaportanspirasi untuk pola tanam tahun 2019 dapat dilhat sebagai berikut :

Contoh Perhitungan Evaportanspirasi (Eto) pada bulan Januari:

Eto $=P \times(0,457 \times t+8,13)$

Eto $=0,29 \times(0,457 \times 32,5+8,13)=6,63$

Tabel 6. Hasil Perhitungan Evapotranspirasi

\begin{tabular}{cllll}
\hline No & Bulan & \multicolumn{1}{r}{$\mathrm{T}$} & \multicolumn{1}{c}{$\mathrm{ET}_{\mathrm{O}}$} \\
\hline 1 & Januari & 32,3 & 0,29 & 6,63 \\
2 & Februari & 32 & 0,28 & 6,36 \\
3 & Maret & 31,9 & 0,28 & 6,35 \\
4 & April & 32,3 & 0,27 & 6,17 \\
5 & Mei & 31,9 & 0,26 & 5,90 \\
6 & Juni & 30 & 0,26 & 5,67 \\
7 & Juli & 26,8 & 0,26 & 5,29 \\
8 & Agustus & 26,6 & 0,27 & 5,46 \\
9 & September & 26,4 & 0,27 & 5,44 \\
10 & Oktober & 31,5 & 0,28 & 6,30 \\
12 & November & 31,8 & 0,28 & 6,34 \\
12 & Desember & 32 & 0,29 & 6,59 \\
\hline
\end{tabular}

Keterangan :

Mencari nilai (P) dari tabel Blaney Criddle berdasarkan letak lintang $7^{\circ} \mathrm{LS}$.

Contoh Letak Lintang $7^{\circ}$ LS pada bulan Januari $=0,29$

Tabel 7. Nilai P untuk Metode Blaney Criddle [14]

\begin{tabular}{|c|c|c|c|c|c|c|c|c|c|c|c|c|}
\hline \multicolumn{13}{|c|}{ Lintang } \\
\hline Utara & Jan & $\mathrm{Feb}$ & Mar & Apr & Mei & Jun & Jul & $\mathrm{Ags}$ & Sep & Okt & Nov & Des \\
\hline Selatan & Jul & $\mathrm{Ags}$ & Sep & Okt & Nov & Des & Jan & $\mathrm{Feb}$ & Mar & Apr & Mei & Jun \\
\hline 60 & 0,15 & 0,2 & 0,26 & 0,32 & 0,38 & 0,41 & 0,4 & 0,34 & 0,28 & 0,22 & 0,17 & 0,13 \\
\hline 50 & 0,19 & 0,23 & 0,27 & 0,31 & 0,34 & 0,36 & 0,35 & 0,32 & 0,28 & 0,24 & 0,2 & 0,18 \\
\hline 40 & 0,22 & 0,24 & 0,27 & 0,3 & 0,32 & 0,34 & 0,33 & 0,31 & 0,28 & 0,25 & 0,22 & 0,21 \\
\hline 30 & 0,24 & 0,25 & 0,27 & 0,29 & 0,31 & 0,32 & 0,31 & 0,3 & 0,28 & 0,26 & 0,24 & 0,23 \\
\hline 20 & 0,25 & 0,26 & 0,27 & 0,28 & 0,29 & 0,3 & 0,3 & 0,29 & 0,28 & 0,26 & 0,25 & 0,25 \\
\hline 10 & 0,26 & 0,27 & 0,27 & 0,28 & 0,28 & 0,29 & 0,29 & 0,28 & 0,28 & 0,27 & 0,26 & 0,26 \\
\hline 0 & 0,27 & 0,27 & 0,27 & 0,27 & 0,27 & 0,27 & 0,27 & 0,27 & 0,27 & 0,27 & 0,27 & 0,27 \\
\hline
\end{tabular}

Mencari data suhu rata - rata bulanan ( $\mathrm{t}$ )

Berdasarkan data klimatologi (SDA Citanduy Purwokerto) pada bulang Januari $=32,3$

\section{Penyiapan Lahan}

Angka kebutuhan air untuk penyiapan lahan didapat dari tabel kebutuhan air selama penyiapan lahan. Jika angka Eo + P tidak terdapat dalam tabel maka dilakukan interpolasi untuk mendapatkan nilai Eo + P. Berikut contoh perhitungan kebutuhan air untuk penyiapan lahan pada bulan Oktober.

Eo $+\mathrm{P}=(1,1 \times$ Eto $)+2=8,14$

Lihat pada tabel kebutuhan air selama penyiapan lahan. Jika nilai Eo + P tidak terdapat pada tabel, maka dilakukan interpolasi.

$$
X=B 1-\frac{A n-A 1}{A 2-A 1} \times B 1-B 2
$$

dengan

An $\quad=9,29$

A1 $=9$ 


$\begin{array}{ll}\text { A2 } & =9,5 \\ \text { B1 } & =15,2 \\ \text { B2 } & =15,5\end{array}$

$$
X=15,2-\frac{9,29-9}{9,5-9} \times 15,2-15,5=15,4
$$

Tabel 8. Penyiapan Lahan (Ir)

\begin{tabular}{clll}
\hline No & Bulan & Eto & Eo + P \\
\hline 1 & Januari & 6,63 & 9,29 \\
2 & Februari & 6,36 & 9,00 \\
3 & Maret & 6,35 & 8,98 \\
4 & April & 6,17 & 8,79 \\
5 & Mei & 5,90 & 8,48 \\
6 & Juni & 5,67 & 8,23 \\
7 & Juli & 5,29 & 7,81 \\
8 & Agustus & 5,46 & 8,01 \\
9 & September & 5,44 & 7,98 \\
10 & Oktober & 6,30 & 8,93 \\
11 & November & 6,34 & 8,97 \\
12 & Desember & 6,59 & 9,25 \\
\hline
\end{tabular}

Tabel 9. Kebutuhan Air Selama Penyiapan Lahan [9]

\begin{tabular}{lllll}
\hline \multicolumn{1}{c}{ Eo $+\mathrm{P}$} & \multicolumn{2}{c}{$\mathrm{T}=30$ Hari } & \multicolumn{2}{c}{$\mathrm{T}=45$ Hari } \\
\hline \multicolumn{1}{c}{$\mathrm{mm} / \mathrm{hari}$} & $\mathrm{S}=250 \mathrm{~mm}$ & $\mathrm{~S}=300 \mathrm{~mm}$ & $\mathrm{~S}=250 \mathrm{~mm}$ & $\mathrm{~S}=300 \mathrm{~mm}$ \\
\hline 5 & 11,1 & 12,7 & 8,4 & 9,5 \\
5,5 & 11,4 & 13 & 8,8 & 9,8 \\
6 & 11,7 & 13,3 & 9,1 & 10,1 \\
6,5 & 12 & 13,6 & 9,4 & 10,4 \\
7 & 12,3 & 13,9 & 9,8 & 10,8 \\
7,5 & 12,6 & 14,2 & 10,1 & 11,1 \\
8 & 13 & 14,5 & 10,4 & 11,4 \\
8,5 & 13,3 & 14,8 & 10,8 & 11,8 \\
9 & 13,6 & 15,2 & 11,2 & 12,1 \\
9,5 & 14 & 15,5 & 11,6 & 12,5 \\
10 & 14,3 & 15,8 & 12 & 12,9 \\
10,5 & 14,7 & 16,2 & 12,4 & 13,2 \\
11 & 15 & 16,5 & 12,8 & 13 \\
\hline
\end{tabular}

Tabel 10. Angka Kebutuhan Air Penyiapan Lahan

\begin{tabular}{clll}
\hline No & Bulan & Ir $(\mathrm{mm} / \mathrm{hr})$ & Ir $(1 / \mathrm{dt})$ \\
\hline 1 & Oktober & 15,14 & 1,75 \\
2 & November & 15,18 & 1,76 \\
3 & Desember & 15,35 & 1,78 \\
4 & Januari & 15,38 & 1,78 \\
5 & Februari & 15,20 & 1,76 \\
6 & Maret & 15,19 & 1,76 \\
7 & April & 15,03 & 1,74 \\
8 & Mei & 14,79 & 1,71 \\
9 & Juni & 14,64 & 1,69 \\
10 & Juli & 14,39 & 1,67 \\
11 & Agustus & 14,51 & 1,68 \\
12 & September & 14,49 & 1,68 \\
\hline
\end{tabular}

\section{Kebutuhan Air Komsumtif}

Penggunaan komsumtif diartikan sebagai jumlah air yang dibutuhkan untuk pertumbuhan tanaman. (Doorenbos dkk., 1977) mendefinisikan kebutuhan air tanaman sebagai jumlah air yang disediakan untuk mengimbangi air yang hilang akibat evaporasi dan transpirasi (evapotranspirasi). Penggunaan komsumtif air di 
dapat dari evapotranspirasi dikalikan dengan angka koefisien tanaman. Padi yang ditanam di areal sawah Daerah Irigasi Serayu yang terlewati oleh saluran sekunder sumpiuh dan selandaka berjenis IR64 yang termasuk padi FAO varietas biasa. Sedangkan tanaman palawijanya diasumsikan tanaman kacang tanah karena sebagian besar petani menanam kacang tanah. Angka kebutuhan air konsumtif sebagai berikut:

Tabel 11. Angka Konsumtif (Etc)

\begin{tabular}{|c|c|c|c|c|c|}
\hline MT & Bulan & Periode & Eto $(\mathrm{mm})$ & $\mathrm{kc}$ & $\begin{array}{c}\text { Etc } \\
(\mathrm{mm} / \mathrm{hari})\end{array}$ \\
\hline \multirow{8}{*}{ MT I } & \multirow{2}{*}{ Okt } & I & 6,30 & 1,10 & 6,93 \\
\hline & & II & 6,30 & 1,10 & 6,93 \\
\hline & \multirow{2}{*}{ Nov } & I & 6,34 & 1,10 & 6,97 \\
\hline & & II & 6,34 & 1,10 & 6,97 \\
\hline & \multirow{2}{*}{ Des } & I & 6,59 & 1,10 & 7,25 \\
\hline & & II & 6,59 & 1,05 & 6,92 \\
\hline & \multirow{2}{*}{ Jan } & I & 6,63 & 0,95 & 6,30 \\
\hline & & II & 6,63 & 0,00 & 0,00 \\
\hline \multirow{8}{*}{ MT II } & \multirow{2}{*}{ Feb } & I & 6,36 & 1,10 & 7,00 \\
\hline & & II & 6,36 & 1,10 & 7,00 \\
\hline & \multirow{2}{*}{ Mar } & I & 6,35 & 1,10 & 6,98 \\
\hline & & II & 6,35 & 1,10 & 6,98 \\
\hline & \multirow{2}{*}{ Apr } & I & 6,17 & 1,10 & 6,79 \\
\hline & & II & 6,17 & 1,05 & 6,48 \\
\hline & \multirow{2}{*}{ Mei } & I & 5,90 & 0,95 & 5,60 \\
\hline & & II & 5,90 & 0,00 & 0,00 \\
\hline \multirow{8}{*}{ MT III } & \multirow{2}{*}{ Jun } & I & 5,67 & 0,5 & 2,83 \\
\hline & & II & 5,67 & 0,51 & 2,89 \\
\hline & \multirow{2}{*}{ Jul } & I & 5,29 & 0,66 & 3,49 \\
\hline & & II & 5,29 & 0,85 & 4,49 \\
\hline & \multirow{2}{*}{$\mathrm{Ags}$} & I & 5,46 & 0,95 & 5,19 \\
\hline & & II & 5,46 & 0,95 & 5,19 \\
\hline & \multirow{2}{*}{ Sep } & I & 5,44 & 0,55 & 2,99 \\
\hline & & II & 5,44 & 0,55 & 2,99 \\
\hline
\end{tabular}

\section{Perkolasi (P)}

Berdasarkan teksturnya angka perkolasi berbeda beda, yaitu :

a. Berat (lempung) $=1-2 \mathrm{~mm} /$ hari

b. Sedang (lempung kepasiran) $=2-3 \mathrm{~mm} / \mathrm{hari}$

c. Ringan $=3-6 \mathrm{~mm} / \mathrm{hari}$

Menurut studi lapangan dan juga mengacu pada penelitian sebelumnya dan terdahulu tekstur tanah di daerah irigasi serayu saluran sekunder sumpiuh dan selandaka adalah sedang (lempung kepasiran), sehingga angka perkolasi diambil $2 \mathrm{~mm} /$ hari.

\section{Penggantian Lapisan Air ( Wlr )}

Penggantian lapisan air dilakukan sebanyak 2 kali, masing-masing $50 \mathrm{~mm} \quad(3,33 \mathrm{~mm} / \mathrm{hari})$ selama sebulan dan dua bulan setelah transplantasi atau pemindahan bibit (Direktorat Jendral Pengairan, 1986). Dalam hal ini, penggantian lapisan air dilakukan pada bulan November dan Januari untuk masa tanam pertama dan bulan Maret dan Mei untuk masa tanam kedua.

Tabel 12. Angka Penggantian Lapisan Air (Wlr)

\begin{tabular}{cccc}
\hline \multirow{2}{*}{ Musim } & \multirow{2}{*}{ Bulan } & Periode & Wlr \\
\cline { 3 - 4 } & Okt & I & \\
\multirow{2}{*}{ MT I } & Nov & II & \\
& & I & 3,33 \\
& Des & II & \\
& & II &
\end{tabular}




\begin{tabular}{cccc} 
& Jan & I & 3,33 \\
\hline & Feb & II & \\
MT II & Mar & II & \\
& & II & 3,33 \\
& Apr & I & \\
& Mei & II & \\
& Jun & II & 3,33 \\
& & I & \\
MT III & Jul & I & \\
& & II & 3,33 \\
& Ags & I & \\
& Sep & II & \\
& & II & 3,33 \\
\hline
\end{tabular}

\section{Kebutuhan Air Irigasi}

Faktor yang mempengaruhi kebutuhan air irigasi yaitu Evapotranspirasi (Eto), Penyiapan Lahan (Ir), Penggunaan Komsumtif Air (Etc), Perkolasi (P), Penggantian Lapisan Air (Wlr), Curah Hujan Efektif (Re), maka kebutuhan air irigasi adalah sebagai berikut:

Tabel 13. Kebutuhan Air Irigasi

\begin{tabular}{|c|c|c|c|c|c|c|c|c|c|c|}
\hline \multirow[t]{2}{*}{ Musim } & \multirow[t]{2}{*}{ Bulan } & \multirow[t]{2}{*}{ Periode } & Etc & \multirow[t]{2}{*}{ Ir } & Wlr & \multirow[t]{2}{*}{$\mathrm{P}$} & \multirow[t]{2}{*}{$\mathrm{Re}$} & \multirow{2}{*}{$\frac{\text { NFR }}{\mathrm{mm} / \text { hari }}$} & \multirow{2}{*}{$\frac{\mathrm{NFR}}{\mathrm{1} / \mathrm{dt} / \mathrm{ha}}$} & \multirow{2}{*}{$\begin{array}{l}\begin{array}{l}\text { Keb.di } \\
\text { intake }\end{array} \\
\text { 1/dt/ha }\end{array}$} \\
\hline & & & $\mathrm{mm} / \mathrm{hri}$ & & KP-01 & & & & & \\
\hline \multirow{8}{*}{ MT I } & \multirow{2}{*}{ Okt } & I & 6,14 & \multirow{2}{*}{1,69} & \multirow{6}{*}{3,33} & \multirow{2}{*}{2} & 0,01 & 9,82 & 1,14 & 1,75 \\
\hline & & II & 6,14 & & & & 0,21 & 9,62 & 1,11 & 1,71 \\
\hline & \multirow{2}{*}{ Nov } & I & 6,16 & \multirow{6}{*}{1,69} & & \multirow{2}{*}{2} & 0,66 & 12,52 & 1,45 & 2,23 \\
\hline & & II & 6,16 & & & & 0,53 & 12,65 & 1,46 & 2,25 \\
\hline & \multirow{2}{*}{ Des } & I & 6,29 & & & \multirow{2}{*}{2} & 0,54 & 7,75 & 0,90 & 1,38 \\
\hline & & II & 6,01 & & & & 0,84 & 7,17 & 0,83 & 1,28 \\
\hline & \multirow{2}{*}{ Jan } & I & 5,40 & & \multirow{2}{*}{3,33} & \multirow{2}{*}{2} & 0,95 & 9,78 & 1,13 & 1,74 \\
\hline & & II & 0,00 & & & & 0,89 & 4,44 & 0,51 & 0,79 \\
\hline \multirow{8}{*}{ MT II } & \multirow{2}{*}{$\mathrm{Feb}$} & I & 6,06 & \multirow{2}{*}{1,51} & & \multirow{2}{*}{2} & 0,79 & 8,78 & 1,02 & 1,56 \\
\hline & & II & 6,06 & & & & 0,78 & 8,79 & 1,02 & 1,57 \\
\hline & \multirow{2}{*}{ Mar } & I & 6,04 & \multirow{6}{*}{1,51} & & \multirow{2}{*}{2} & 0,52 & 12,36 & 1,43 & 2,20 \\
\hline & & II & 6,04 & & 3,33 & & 0,70 & 12,18 & 1,41 & 2,17 \\
\hline & \multirow{2}{*}{ Apr } & I & 5,82 & & & \multirow{2}{*}{2} & 0,68 & 7,14 & 0,83 & 1,27 \\
\hline & & II & 5,55 & & & & 0,52 & 7,03 & 0,81 & 1,25 \\
\hline & & I & 4,85 & & 202 & & 0,14 & 10,04 & 1,16 & 1,79 \\
\hline & Mei & II & 0,00 & & 3,33 & 2 & 0,23 & 5,10 & 0,59 & 0,91 \\
\hline & & I & 0,00 & & & & 0,11 & 1,89 & 0,22 & 0,34 \\
\hline & Jun & II & 0,00 & & & 2 & 0,06 & 1,94 & 0,22 & 0,35 \\
\hline & & I & 2,52 & & 202 & & 0,00 & 7,85 & 0,91 & 1,40 \\
\hline & Jul & II & 2,97 & & 3,33 & 2 & 0,00 & 8,30 & 0,96 & 1,48 \\
\hline MT III & & I & 5,12 & & & 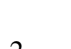 & 0,00 & 7,12 & 0,82 & 1,27 \\
\hline & Ags & II & 5,60 & & & 2 & 0,00 & 7,60 & 0,88 & 1,35 \\
\hline & $\mathrm{S}_{0}$ & I & 5,44 & & 202 & 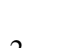 & 0,00 & 10,77 & 1,25 & 1,92 \\
\hline & Sep & II & 5,06 & & 3,33 & 2 & 0,00 & 10,39 & 1,20 & 1,85 \\
\hline
\end{tabular}

Dari tabel 13. untuk kebutuhan air irigasi dikalikan dengan luas areal sawah saluran sekunder sumpiuh dan selandaka, sehingga dapat diketahui angka kebutuhan air irigasi saluran sekunder sumpiuh dan selandaka daerah irigasi serayu:

Kebutuhan Air Irigasi di Daerah Irigasi Serayu Kecamatan Sumpiuh Kabupaten Banyumas (Teguh Marhendi) 
Tabel 14. Kebutuhan Air Irigasi Sekunder Sumpiuh

\begin{tabular}{|c|c|c|c|c|c|}
\hline \multirow[t]{2}{*}{ Musim } & \multirow[t]{2}{*}{ Bulan } & \multirow[t]{2}{*}{ Periode } & Keb.di intake & $\begin{array}{c}\text { Luas Areal } \\
\text { SS Sumpiuh }\end{array}$ & $\begin{array}{l}\text { Kebutuhan Air } \\
\text { Irigasi }\end{array}$ \\
\hline & & & 1/dt/ha & ha & $1 \mathrm{t} / \mathrm{dt}$ \\
\hline \multirow{8}{*}{ MT I } & \multirow{2}{*}{ Okt } & I & 1,90 & 172 & 327,08 \\
\hline & & II & 1,89 & 172 & 324,93 \\
\hline & \multirow{2}{*}{ Nov } & I & 2,45 & 172 & 422,22 \\
\hline & & II & 2,46 & 172 & 423,14 \\
\hline & \multirow{2}{*}{ Des } & I & 1,60 & 172 & 274,65 \\
\hline & & II & 1,53 & 172 & 263,03 \\
\hline & \multirow{2}{*}{ Jan } & I & 1,98 & 172 & 340,49 \\
\hline & & II & 0,85 & 172 & 147,01 \\
\hline \multirow{8}{*}{ MT II } & \multirow{2}{*}{ Feb } & I & 1,84 & 172 & 316,28 \\
\hline & & II & 1,85 & 172 & 318,43 \\
\hline & \multirow{2}{*}{ Mar } & I & 2,43 & 172 & 417,79 \\
\hline & & II & 2,45 & 172 & 420,55 \\
\hline & \multirow{2}{*}{ Apr } & I & 1,49 & 172 & 256,31 \\
\hline & & II & 1,47 & 172 & 252,98 \\
\hline & \multirow{2}{*}{ Mei } & I & 1,92 & 172 & 330,78 \\
\hline & & II & 0,94 & 172 & 161,10 \\
\hline \multirow{8}{*}{ MT III } & \multirow{2}{*}{ Jun } & I & 0,85 & 172 & 146,82 \\
\hline & & II & 0,87 & 172 & 149,79 \\
\hline & \multirow{2}{*}{ Jul } & I & 1,57 & 172 & 270,08 \\
\hline & & II & 1,75 & 172 & 300,83 \\
\hline & \multirow{2}{*}{$\mathrm{Ags}$} & I & 1,28 & 172 & 220,22 \\
\hline & & II & 1,28 & 172 & 220,22 \\
\hline & \multirow{2}{*}{ Sep } & I & 1,48 & 172 & 254,86 \\
\hline & & II & 1,48 & 172 & 254,86 \\
\hline
\end{tabular}

Tabel 15. Kebutuhan Air Irigasi Sekunder Selandaka

\begin{tabular}{|c|c|c|c|c|c|}
\hline \multirow[t]{2}{*}{ Musim } & \multirow[t]{2}{*}{ Bulan } & \multirow[t]{2}{*}{ Periode } & Keb.di intake & $\begin{array}{c}\text { Luas Areal } \\
\text { SS Sendakala }\end{array}$ & $\begin{array}{c}\text { Kebutuhan Air } \\
\text { Irigasi }\end{array}$ \\
\hline & & & 1/dt/ha & ha & $1 \mathrm{t} / \mathrm{dt}$ \\
\hline \multirow{8}{*}{ MT I } & \multirow{2}{*}{ Okt } & I & 1,90 & 16 & 30,43 \\
\hline & & II & 1,89 & 16 & 30,23 \\
\hline & \multirow{2}{*}{ Nov } & I & 2,45 & 16 & 39,28 \\
\hline & & II & 2,46 & 16 & 39,36 \\
\hline & \multirow{2}{*}{ Des } & I & 1,60 & 16 & 25,55 \\
\hline & & II & 1,53 & 16 & 24,47 \\
\hline & \multirow{2}{*}{ Jan } & I & 1,98 & 16 & 31,67 \\
\hline & & II & 0,85 & 16 & 13,68 \\
\hline \multirow{8}{*}{ MT II } & \multirow{2}{*}{ Feb } & I & 1,84 & 16 & 29,42 \\
\hline & & II & 1,85 & 16 & 29,62 \\
\hline & \multirow{2}{*}{ Mar } & I & 2,43 & 16 & 38,86 \\
\hline & & II & 2,45 & 16 & 39,12 \\
\hline & \multirow{2}{*}{ Apr } & I & 1,49 & 16 & 23,84 \\
\hline & & II & 1,47 & 16 & 23,53 \\
\hline & \multirow{2}{*}{ Mei } & I & 1,92 & 16 & 30,77 \\
\hline & & II & 0,94 & 16 & 14,99 \\
\hline \multirow{8}{*}{ MT III } & \multirow{2}{*}{ Jun } & I & 0,85 & 16 & 13,66 \\
\hline & & II & 0,87 & 16 & 13,93 \\
\hline & \multirow{2}{*}{ Jul } & I & 1,57 & 16 & 25,12 \\
\hline & & II & 1,75 & 16 & 27,98 \\
\hline & \multirow{2}{*}{ Ags } & I & 1,28 & 16 & 20,49 \\
\hline & & II & 1,28 & 16 & 20,49 \\
\hline & \multirow{2}{*}{ Sep } & I & 1,48 & 16 & 23,71 \\
\hline & & II & 1,48 & 16 & 23,71 \\
\hline
\end{tabular}

CIVeng Vol.2, No.2, Juli 2021 : 43 58 
Analisis Perbandingan Kebutuhan Air Irigasi Hasil Perhitungan Dengan Realisasi Di Lapangan

\begin{tabular}{|c|c|c|c|c|c|c|c|c|}
\hline \multirow[t]{2}{*}{ Musim } & \multirow[t]{2}{*}{$\begin{array}{c}\text { Bulan } \\
19 / 20\end{array}$} & \multirow[t]{2}{*}{ Periode } & $\begin{array}{c}\text { Keb Air Irigasi } \\
\text { SS Sumpiuh } \\
\text { Perhitungan }\end{array}$ & $\begin{array}{c}\text { Keb Air Irigasi } \\
\text { SS Selandaka } \\
\text { Perhitungan }\end{array}$ & \multirow[t]{2}{*}{$\begin{array}{l}\text { Bulan } \\
19 / 20\end{array}$} & \multirow[t]{2}{*}{ Periode } & \multirow{2}{*}{$\begin{array}{c}\text { Keb Air } \\
\text { Irigasi SS } \\
\text { Sumpiuh } \\
\text { Lapangan } \\
\text { lt/dt }\end{array}$} & \multirow{2}{*}{$\begin{array}{c}\text { Keb Air Irigas } \\
\begin{array}{c}\text { SS Selandaka } \\
\text { Lapangan }\end{array} \\
\text { lt/dt }\end{array}$} \\
\hline & & & $1 \mathrm{t} / \mathrm{dt}$ & $\mathrm{lt} / \mathrm{dt}$ & & & & \\
\hline \multirow{8}{*}{ MT I } & \multirow{2}{*}{ Okt } & I & 327,08 & 30,43 & \multirow{2}{*}{ Okt } & I & - & - \\
\hline & & II & 324,93 & 30,23 & & II & 267,00 & 25,00 \\
\hline & \multirow{2}{*}{ Nov } & I & 422,22 & 39,28 & \multirow{2}{*}{ Nov } & I & - & - \\
\hline & & II & 423,14 & 39,36 & & II & 154,00 & 13,00 \\
\hline & \multirow{2}{*}{ Des } & I & 274,65 & 25,55 & \multirow{2}{*}{ Des } & I & 160,00 & 13,00 \\
\hline & & II & 263,03 & 24,47 & & II & 209,00 & 17,00 \\
\hline & \multirow{2}{*}{ Jan } & I & 340,49 & 31,67 & \multirow{2}{*}{ Jan } & I & 168,00 & 13,00 \\
\hline & & II & 147,01 & 13,68 & & II & 154,00 & 13,00 \\
\hline \multirow{8}{*}{ MT II } & \multirow{2}{*}{ Feb } & I & 316,28 & 29,42 & \multirow{2}{*}{ Feb } & I & 154,00 & 13,00 \\
\hline & & II & 318,43 & 29,62 & & II & 154,00 & 13,00 \\
\hline & \multirow{2}{*}{ Mar } & I & 417,79 & 38,86 & \multirow{2}{*}{ Mar } & I & 145,00 & 8,00 \\
\hline & & II & 420,55 & 39,12 & & II & - & - \\
\hline & \multirow{2}{*}{ Apr } & I & 256,31 & 23,84 & \multirow{2}{*}{ Apr } & I & 136,00 & - \\
\hline & & II & 252,98 & 23,53 & & II & 257,00 & 24,00 \\
\hline & \multirow{2}{*}{ Mei } & I & 330,78 & 30,77 & \multirow{2}{*}{ Mei } & I & 257,00 & 20,00 \\
\hline & & II & 161,10 & 14,99 & & II & 232,00 & 14,00 \\
\hline \multirow{8}{*}{ MT III } & \multirow{2}{*}{ Jun } & I & 146,82 & 13,66 & \multirow{2}{*}{ Jun } & I & 151,00 & 13,00 \\
\hline & & II & 149,79 & 13,93 & & II & 151,00 & 14,00 \\
\hline & \multirow{2}{*}{ Jul } & I & 270,08 & 25,12 & \multirow{2}{*}{ Jul } & I & 151,00 & 14,00 \\
\hline & & II & 300,83 & 27,98 & & II & 151,00 & 14,00 \\
\hline & \multirow{2}{*}{ Ags } & I & 220,22 & 20,49 & \multirow{2}{*}{ Ags } & I & - & - \\
\hline & & II & 220,22 & 20,49 & & II & - & - \\
\hline & & I & 254,86 & 23,71 & & I & - & - \\
\hline & Sep & II & 254,86 & 23,71 & Sep & II & 267,00 & 25,00 \\
\hline
\end{tabular}

Pada tabel diatas dapat dilihat perbandingan besaran kebutuhan air irigasi yang ada pada saluran sekunder sumpiuh dan selandaka secara perhitungan dan yang ada di lapangan. Kebutuhan air irigasi hasil perhitungan merupakan hasil olahan data kebutuhan dan faktor pendukung yang ada untuk mengetahui besaran air irigasi yang dibutuhkan. Sedangkan Kebutuhan air irigasi di lapangan adalah besaran realisasi kebutuhan air irigasi yang diberikan ke sawah-sawah dari saluran sekunder sumpiuh dan selandaka.

Maka dari itu dari tabel tersebut dapat dijelaskan sebagai berikut:

a. Pada kebutuhan air irigasi saluran sekunder sumpiuh hasil perhitungan, angka terbesarnya ada pada MT I bulan November periode II yaitu 423,14 lt/dt sedangkan angka terkecilnya di MT III bulan Juni periode 1 yaitu 146,82 lt/dt. Lalu kebutuhan air irigasi saluran sekunder sumpiuh di lapangan, angka terbesarnya ada pada MT I bulan Oktober periode II dan MT III bulan September periode II yaitu 267,00 1t/dt sedangkan angka terkecilnya di MT II bulan April periode 1 yaitu 136,00 lt/dt.

b. Pada kebutuhan air irigasi saluran sekunder selandaka hasil perhitungan, angka terbesarnya ada pada MT I bulan November periode II yaitu 13,66 lt/dt sedangkan angka terkecilnya di MT III bulan Juni periode 1 yaitu 39,36 lt/dt. Lalu kebutuhan air irigasi saluran sekunder sumpiuh di lapangan, angka terbesarnya ada pada MT I bulan Oktober periode II dan MT III bulan September periode II yaitu 25,00 1t/dt sedangkan angka terkecilnya di MT II bulan Maret periode 1 yaitu 8,00 lt/dt.

\section{KESIMPULAN}

Berdasarkan hasil penelitian dapat ditarik beberapa kesimpulan sebagai berikut :

1. Pada kebutuhan air irigasi saluran sekunder sumpiuh hasil perhitungan, angka terbesarnya ada pada MT I bulan November periode II yaitu 423,14 lt/dt sedangkan angka terkecilnya di MT III bulan Juni periode 1 yaitu 146,82 lt/dt. Lalu kebutuhan air irigasi saluran sekunder sumpiuh di lapangan, angka terbesarnya ada pada MT I bulan Oktober periode II dan MT III bulan September periode II yaitu 267,00 1t/dt sedangkan angka terkecilnya di MT II bulan April periode 1 yaitu 136,00 lt/dt. 
2. Pada kebutuhan air irigasi saluran sekunder selandaka hasil perhitungan, angka terbesarnya ada pada MT I bulan November periode II yaitu 13,66 lt/dt sedangkan angka terkecilnya di MT III bulan Juni periode 1 yaitu 39,36 lt/dt. Lalu kebutuhan air irigasi saluran sekunder sumpiuh di lapangan, angka terbesarnya ada pada MT I bulan Oktober periode II dan MT III bulan September periode II yaitu 25,00 lt/dt sedangkan angka terkecilnya di MT II bulan Maret periode 1 yaitu 8,00 lt/dt.

\section{DAFTAR PUSTAKA}

[1] Badan Pusat Statistik Kabupaten Banyumas, 2016, Luas Lahan Sawah Menurut Jenis Pengairan.

[2] Teguh Marhendi, Ali Imron, 2020, Model Angkutan Sedimen untuk Analisis Peningkatan Sedimen di Hulu Bendung Gerak Serayu, Jurnal Techno Vol 21 No 1, April 2020.

[3] Priyonugroho, Anton, 2014, Analisis Kebutuhan Air Irigasi (Studi Kasus Pada Daerah Irigasi Sungai Air Keban Daerah Kabupaten Empat Lawang).

[4] Purwanto, dkk, 2010, Analisis Kebutuhan Air Irigasi Pada Daerah Irigasi Bendung Mrican1.

[5] Kurniawan, Kuat Iqlas, 2011, Bendung Gerak Serayu.

[6] Website: Https://Junaidawally.Blogspot.Com/2013/09/Kebutuhan-Air-Irigasi.Html. Diakses Pada: 27 Februari 2020

[7] Google Maps, 2020

[8] Sudjarwadi, 1990, Teori dan Praktek Irigasi. Pusat Antar Universitas Ilmu Teknik. UGM. Yogyakarta.

[9] Direktorat Jenderal Pengairan, 1986, Standar Perencanaan Irigasi (KP. 01-05). Departemen Pekerjaan Umum. CV. Galang Persada, Bandung

[10] Ulya, 2019, Pengertian Sistem Irigasi Pertanian Menurut Pakar. Website: Https://Ulyadays.Com/Irigasi/

[11] Ismu Tribowo, 2014, Pengembangan Dan Implementasi Teknologi Irigasi Hemat Air. LIPI

[12] Nurdianza, A., 2011, Pengujian Sistem Irigasi Tetes (Drip Irrigation) Untuk Tanaman Strawberri (Fragaria Vesca L). Universitas Hasanuddin, Makassar

[13] Pradana, Yudha Adi, 2017, Pola Tanam. Website: http://bbplm-jakarta.kemendesa.go.id/view/detil/205/pola-tanam. Diakses pada: 12 April 2020

[14] Arsyad, Sitanala, 1989, Konservasi Tanah dan Air. Penerbit IPB Press. Bogor

[15] Kartasapoetra, A.G., Mul. Mulyani., dan F. Pollein, 1990, Teknologi Pengairan Pertanian (Irigasi). Bumi Aksara. Jakarta.

[16] Suroso, Nugroho, dan Pasrah Pamuji, 2006, Evaluasi Kinerja Jaringan Irigasi Banjaran Untuk Meningkatkan Efektifitas Dan Efisiensi Pengelolaan Air Irigasi. Digital Collection UPT Perpustakaan UNSOED. Universitas Jenderal Soedirman.

[17] Balai PSDA Serayu Citanduy, 2020, Peta Jaringan irigasi Daerah Irigasi Serayu 